\title{
THE CAUSES OF EXTINCTION OF MAMMALIA
}

\author{
HENRY FAIRFIELD OSBORN
}

IN studying the past history ${ }^{1}$ of the Mammalia we find that in some cases the causes of the extinction are as obscure as in other cases they are obvious. I have thus been led to review the subject very carefully, gathering opinions and observations from various sources. I especially desire to arouse discussion and to receive criticisms and suggestions which will be warmly welcomed. ${ }^{2}$

\section{History OF OpINION}

We find that while the main trend of present inquiry as to the external causes of extinction had been suggested by the middle of the nineteenth century, subsequent discoveries and observations furnish new and exact materials for induction both as to external and internal causes.

Cuvier, Lyell, Darwin.-The 'cataclysmal' views of Cuvier, ${ }^{3}$ of wholesale destructions brought about by sudden and great geological changes, naturally gave way to the 'uniformitarian' views gradually developed from the time of Buffon to that of Darwin. The notions of the similarity of past and present causes. of the survival of the fittest, of internal causes of variation, development, and decline, gradually took their modern form. Whewell ${ }^{4}$ clearly sets forth the opinions which developed between 1796 and

${ }^{1}$ Especially in connection with a monograph for the U. S. Geological Survey, entitled "The Titanotheres," which has been in preparation since 1900. This series of articles in the Naturalist will be embodied in somewhat modified form in the monograph.

${ }^{2}$ Address, Professor Henry Fairfield Osborn, American Museum of Natural History, New York.

${ }^{3}$ Cuvier, George. Discours sur les révolutions de la surface du globe et sur les changements qu'ils ont produits dans le regne animal. Paris, 1840, 1 vol. in 8 vo.

${ }^{4}$ Whewell, -. History of the Inductive Sciences, vol. 3, 1837. 
1837. Charles Lyell ${ }^{1}$ gave the note for modern methods of research, greatly influenced Darwin, and perhaps exaggerated uniformitarianism.

In this very problem of extinction, however, uniformitarianism has a stout opponent in Henry H. Howarth. In his extremely interesting work The Mammoth and the Flood (London, 1878) he revives the theory of the destructive flood and marshals a vast number of facts to its support. "These facts," he observes (p. xvii), "I claim prove several conclusions. They prove that a very great catastrophe or cataclysm occurred at the close of the Mammoth period, by which that animal, with its companions, were [!] overwhelmed over a very large part of the Earth's surface. Secondly, that this catastrophe involved a very widespread flood of water, which not only killed the animals but also buried them under continuous beds of loam or gravel. 'Thirdly, that the same catastrophe was accompanied by a very great and sudden change of climate in Siberia, by which the animals which had previously lived in fairly temperate conditions were frozen in their flesh under ground and have remained frozen ever since."

The causes enumerated by Lyell in his later edition of the Principles of Geology after the publication of Darwin's Voyage and Origin are: (1) competition as affected chiefly by the introduction and extension of new forms, (2) agency of insects, e.g., caterpillars, ants, locusts, in favoring or checking increase of plants and thus affecting the food supply of animals, (3) intimate reciprocal relations of animals and plants in the delicate balance of food supply, (4) disturbance of the equilibrium or balance of nature by the introduction of new insects, plants, vertebrated animals, (5) changes in physical geography affecting zoölogical and botanical provinces by new land or water connections, facilitating introduction of new competing forms, (6) causes especially potent in island life.

Referring to that subtle adjustment of the sum of all internal and external causes called the balance of nature, Lyell ${ }^{2}$ observed:

"Every new condition in the state of the organic or inorganic

${ }^{1}$ Lyell, Charles. Principles of Geology, 1872.

${ }^{2}$ Lyell, Charles. Principles of Groology, vol. 2, New York, 1872, pp. 455456 . 
creation, a new animal or plant, an additional snow-clad mountain, any permanent change, however slight in comparison to the whole, gives rise to a new order of things, and may make a material change in regard to some one or more species. Yet a swarm of locusts, or a frost of extreme intensity, or an epidemic disease, may pass away without any great apparent derangement; no species may be lost, and all may soon recover their former relative numbers, because the same scourges may have visited the region again and again, at preceding periods. Every plant that was incapable of resisting such a degree of cold, every animal which was exposed to be entirely cut off by an epidemic or by famine caused by the consumption of vegetation by the locusts, may have perished already, so that the subsequent recurrence of similar catastrophes is attended only by a temporary change."

Even as a geologist Lyell was very cautious, certainly too cautious, in estimating the destructive influence of geologic and physiographic changes. In 1863 (Antiquity of Man, ${ }^{1}$ p. 374), he observed:

"It is probable that causes more general and powerful than the agency of Man, alterations in climate, variations in the range of many species of animals, vertebrate and invertebrate, and of plants, geographical changes in the height, depth, and extent of land and sea, some or all of these combined, have given rise, in a vast series of years, to the annihilation, not only of many large mammalia, but to the disappearance of the Cyrena fuminalis, once common in the rivers of Europe, and to the different range or relative abundance of other shells which we find in the European drifts."

Charles Darwin ${ }^{2}$ pursues a line of thought exactly prophetic to that of Lyell in discussing the Pliocene and post-Pliocene extinction of the large mammals of South America. He dismisses any catastrophic causes and in general attributes extinction to a cessation of those world-wide conditions of life which were favorable to the larger quadrupeds in Europe, Asia, Australia, North and

${ }^{1}$ Lyell, Charles. Geological Evidences of the Antiquity of Man, 2d ed., revised, 8vo, London, 1863, p. 374.

${ }^{2}$ Darwin, Charles. Journal of Researches....Voyage of H. M. S. Beagle, 8vo, 1834, pp. 169, 170. 
South America. In South America and elsewhere (1) he does not favor the extreme theory of the destructive influence of the Glacial Epoch and he cites the supposed post-Glacial survival of Macrauchenia and Mastodon. "It could hardly have been a change of temperature," he observes (p. 170), "which at about the same time destroyed the inhabitants of tropical, temperate, and arctic latitudes on both sides of the globe." (2) He dismisses the possibility of extinction by man. (3) Also of an extended drought in South America, calling attention to the Pampean horse as an animal which could have survived a drought.

In seeking to establish a general law of extinction Darwin makes the following propositions: (1) the natural increase of animals is in geometrical ratio, while, (2) the food supply remains constant, thus (3) any great increase in numbers is impossible and must be checked by some means. (4) We are seldom able to state the cause of this check beyond saying that it is determined by some slight difference in climate, food, or the number of enemies. (5) We are, therefore, driven to the conclusion that causes generally quite inappreciable by us determine whether a given species shall be abundant or scanty in numbers. (6) Comparative rarity is the plainest evidence of less favorable conditions of existence. (7) Rarity frequently precedes extinction, and if the too rapid increase of species, even the most favored, is steadily checked, why should we feel such great astonishment at the rarity being carried a step farther to extinction.

These were Darwin's earlier views expressed in The Voyage. In The Origin of Species he discusses fully the checks to increase as follows: (1) climate as directly unfavorable, (2) as indirectly unfavorable by favoring other forms or by increasing the number of certain competitors. (3) Unchecked increase frequently followed by epidemics - possibly in part by facility of diffusion of parasites amongst the crowded animals. (4) Finally, since a large stock of individuals, relatively to the number of enemies, is absolutely necessary for the preservation of a species a diminished number would tend to extinction. (5) Any form (p. 133) which is represented by few individuals will run a good chance of utter extinction, during great fluctuations in the nature of the seasons, or from a temporary increase in the number of its enemies. (6) Diminution 
in number presents less opportunity for producing favorable variations - hence rare species will be less quickly modified or improved within any given period.

Alfred Russell Wallace observes: "To discover how the extinct species have from time to time been replaced by new ones down to the very latest geological period, is the most difficult, and at the same time the most interesting problem in the natural history of the earth." Also: "Whenever the physical or organic conditions change to however small an extent, some corresponding change will be produced in the flora and fauna, since, considering the severe struggle for existence and the complex relations of the various organisms, it is hardly possible that the change should not be beneficial to some species and hurtful to others." 2

The majority of these speculations of these great naturalists have been abundantly confirmed. The opinions of many subsequent writers on this subject may be stated under their proper headings.

\section{External Causes of Extinction}

\section{Physical Environment. Geological and Physiographic} Changes

We may first consider those causes of extinction which originate with changes in the environment.

\section{Changes of Land Masses and their Connections}

Changes of land masses caused by elevation or subsidence operate indirectly through causing changes in all the physical conditions of climate, moisture, or dessication, temperature, etc.; also more directly in facilitating or cutting off migrations, in introducing new competition, etc.

Diminished or Contracted Land Areas. - The stable continents, North America and Africa, underwent slight fluctuations of land area in Tertiary times as compared with the highly unstable continents of Europe, of Australia, and of the southern half of South

${ }^{1}$ Wallace, Alfred R. Natural Selection, p. 14.

${ }^{2}$ Wallace, Alfred R. Darwinism, 1889, p. 115. 
America. In Europe the varying coast lines, the insular conditions, the archipelagic surfaces are to be more seriously studied than they have been in connection with extinction, although it must be stated at once that the main phenomena of extinction in unstable Europe coincide with those in stable America.

Wallace discussed the extinction of the large Pliocene Australian mammals chiefly from this standpoint (see also p. 785). He (Geog. Dist. Mam., 1876, vol. 1, pp. 158-159) attributed the Australian extinction chiefly to the possible glacial conditions and to the increased competition and struggle for existence caused by the progressively contracted land area due to subsidence.

The substitution of insular for continental conditions by subsidence has undoubtedly been a potent cause both of extermination in certain localities and of the survival of very primitive forms (Wallace), e. g., Monotremata and Marsupialia in Australia. While the contraction of land areas may have resulted in general extinction, this has not yet been demonstrated.

Insular Conditions. - On islands we observe local dwarfing and extinction rather than the general extinction of a family or order which is our real subject. Of island life, so thoroughly studied by Wallace, it may be said at once that most of the causes both of survival and extinction which prevail on continents are intensified on islands. Wallace rightly attributes the survival of the Monotremata and Marsupialia to the practically insular condition of the Australian region. Lyell, Wallace, and others cite many instances of profound and rapid modifications caused by the introduction of new forms on islands.

\section{Physical Environment. Changes of Chimate}

We have to consider temperature and moisture as brought about. by geologic and physiographic changes, and also as affected by biotic changes or changes in the fauna and flora.

\section{Increasing Cold}

Infuence of Secular Cold.- The effects of secular lowering of temperature must be analyzed with some care. At first sight 
the theory of extinction through the direct action of cold is very simple, but it is found that some cases of extinction during the Glacial Period, of the horse in North America for example, do not admit of this explanation. It is more in accord with the facts to say that the Glacial Period originated certain new conditions of life which hastened extinction; these conditions relate to enforced migration, to overcrowding, to feeding, reprorluction, mating, relations to enemies, deforestation, and other indirect results.

Protective Adaptation to Secular Cold.-Resistance to cold depends upon $(a)$ internal heat-producing power which is a progressive adaptation of the higher Mammalia, $(b)$ the acquisition of a warm external covering. The well known cases of adaptation to extreme cold among the elephants (E. primigenius, woolly mammoth), rhinoceroses (R. tichorhinus, woolly rhinoceros), horses (E. przewalskii), and certain northern ruminants, such as the camels and musk oxen, show that we must not assume that cold was in all cases the sole or direct cause of extinction.

Glacial and Post-Glacial Extinction. - Wallace observes: "....We have proof in both Europe and North America, that just about the time these large animals were disappearing, all the northern parts of these continents were wrapped in a mantle of ice; and we have every reason to believe that the presence of this large quantity of ice (known to have been thousands of feet if not some miles in thickness) must have acted in various ways to have produced alterations of level of the ocean as well as vast local floods, which would have combined with the excessive cold to destroy animal life." " And again: "...W we can therefore hardly fail to be right in attributing the wonderful changes in animal and vegetable life that have occurred in Europe and North America between the Miocene period and the present day, in part at least, to the two or more cold epochs that have probably intervened. These changes consist, first, in the extinction of a whole host of the higher animal forms; and, secondly, in a complete change of types due to extinction and emigration, leading to a much greater difference between the vegetable and animal forms of the Eastern and Western hemispheres than before existed."’

${ }^{1}$ Geographical Distribution of Animals, vol. 2, p. 151.

${ }^{2}$ Wallace, A. R. Island Life, 1881, p. 117. 
Certainly the most direct instance of a great extinction of quadrupeds contemporaneous with a secular change of climate is that of the Glacial Period in the entire northern hemisphere. The close of the Pliocene or beginning of the Pleistocene found North America peopled with the following kinds of great quadrupeds, all of which disappeared during the Ice Age.

$\begin{array}{lll}\text { Artiodactyla } & \text { Camelidæ } & \begin{array}{l}\text { Camels } \\ \text { Llamas }\end{array} \\ \text { Perissodactyla } & \text { Equidæ } & \text { Horses } \\ & \text { Tapiridæ } & \text { Tapirs } \\ \text { Proboscidea } & \text { Mastodontinæ } & \text { Mastodons } \\ & \text { Elephantinæ } & \text { Elephants } \\ \text { Edentata } & \text { Gravigrada } & \text { Giant Sloths } \\ & & \text { Megalonyx } \\ & & \text { Megatherium } \\ & & \text { Paramylodon } \\ & \text { Glyptodontia } & \text { Glyptotherium }\end{array}$

Numerical Diminution of Camelida.-The Glacial Period was heralded by increasingly severe winters and cold waves. The observations of Prichard in Patagonia throw a light on the numerical diminution of the Camelidæ.

"Around the lake lay piled the skulls and bones of dead game, guanaco (Lama huanachus) and a few huemules (Furcifer chilensis). These animals come down to live on the lower ground and near unfrozen water during the cold season, and there, when the weather is particularly severe, they die in crowds. We saw their skeletons, in one or two places literally heaped one upon the other" (Through the Heart of Patagonia, 1902, p. 132). "Again we came upon a second death-place of guanaco, which made a scene strange and striking enough. There cannot have been less than five hundred lying there in positions forced and ungainly as the most ill-taken snapshot photograph could produce. Their long necks were outstretched, the rime of the weather upon their decaying hides, and their bone-joints glistening through the wounds made by the beaks of carrion-birds. They had died during the severities of the previous winter, and lay literally piled one upon another" (op. cit., p. 189). "The meaning of this I gathered from Mr. Ernest Cattle. He told me that in the winter of 1899 enor- 
mous numbers of guanaco sought Lake Argentino, and died of starvation upon its shores. In the severities of winter they seek drinking-places, where there are large masses of water likely to be unfrozen. The few last winters in Patagonia have been so severe as to work great havoc among the herds of guanaco" (op. cit., p. 255).

Deforestation and Secular Cold.-After considering the conditions in Alaska, Mr. A. G. Maddren ${ }^{1}$ summarizes his conclusions $^{2}$ as follows: "I. That while remnants of the large Pleistocene mammal herds may have survived down to the Recent period and in some cases their direct descendants, as the musk-ox, to the present, most of them became extinct in Alaska with the close of the Pleistocene.

"II. The most rational way of explaining this extinction of animal life is by a gradual changing of the climate from more temperate conditions permitting of a forest vegetation much farther north than now, to the more severe climate of today, which subduing the vegetation and thus reducing the food supply besides directly discomforting the animals themselves, has left only those forms capable of adapting themselves to the Recent conditions surviving in these regions to the present."

Influence of Cold and Snow on Food Supply and Choice of Food. - The deaths of great numbers of animals from hunger or starvation through the covering of food during the winter season under heavy layers of snow are commonly observed among the large herds of some of the domesticated horses and cattle on the Western plains. In fact, it is most probable that during the glacial period the great winter snow blankets covering the natural food rather than the actual influence of the cold itself, was the chief cause of extinction.

Under these conditions horses are driven to food, such as the branches of willows, which is very deleterious to them. Under the influence of hunger cattle and sheep also will feed eagerly and indiscriminately on plants which may be injurious to them or to their young, as recorded by Chestnut and others in the United.

${ }^{1}$ Maddren, A. G. "Smithsonian Exploration in Alaska in 1904, in Search of Mammoth and other Fossil Remains." Smiths. Misc. Coll., vol. 49, p. 65. 
States Agricultural Department. The indirect results of hunger may be, therefore, quite as effective as actual starvation.

Animals vary greatly in adaptability to new conditions caused by prolonged cold and heavy snowfall. Horses remove snow even to depths of three or four feet and find food to carry them through the winter, while cattle under the same conditions starve.

An interesting instance of the effects of a temporary lowering of temperature in a subtropical region is that cited by Bangs of the influence of an unusual cold wave in the habitat of one of the Sirenia (Manatus manatus) in the rivers of Florida in the winter of 1895 . The author observed that an unusual cold wave cut down all the leaves of the mangrove, a favorite food of the manatee at certain seasons. This was followed by a marked numerical diminution of the manatee. ${ }^{1}$

Dangers of Numerical Diminution and Diminished Herds.While distinction must be drawn between actual extinction and a temporary diminution in numbers caused, for example, by cold waves, prolonged or repeated droughts, floods, epidemics, and other unfavorable conditions of life, it is very important to observe, as suggested by Darwin, that diminution in numbers may lead to extinction in certain cases. For example, a herd of animals may be reduced to the danger point in numbers where they can no longer protect their young. Director Bell of the Canadian Geological Survey believes that the small herd of Woodland Bison of British Columbia, now thoroughly protected by the government, will be destroyed gradually through the killing of the calves by wolves, the bulls not being sufficiently numerous to protect the calves.

Diminished Herds and Inbreeding.-Diminished herds in restricted regions may also disappear through too close inbreeding. On this familiar subject see Gerrit S. Miller's" paper "Fate of the European Bison Herd," in which the author shows the possibly fatal influence of inbreeding on diminished herds, although it must be pointed out that the animals are protected and are thus living under unnatural conditions.

${ }^{1}$ Mr. C. H. Townsend, from observations in the New York Aquarium, is inclined to attribute this diminution to the respiration of the frosty air.

${ }^{2}$ Miller, Gerrit S., Jr. "The Fate of the European Bison Herd." Science, n. s., vol. 4, no. 99 , Nov. 20, 1886, pp. 744-745. 
In a paper entitled "Das allmähliche Aussterben des Wisents (Bison bonasus Linn.) im Forste von Bjelowjesha"," Mr. Eugen Büchner gives a detailed history of the bison herd in the Bieloviejsha (or Bialowitza) forest, Province of Grodno, in Lithuania, Russia, during the present century. "A careful study of the breeding habits of the bison in the Bieloviejsha forest and elsewhere leaves no room for doubt that the present slow rate of reproduction is an abnormal condition, and that to it is due the rapid approach of the extinction which is the certain fate of the herd under consideration. This diminished fertility the author regards as a stigma of degeneration caused by in-breeding.... Another indication of the degenerate condition of the Bieloviejsha herd is seen in the great excess of bulls, which probably outnumber the cows two to one. This is doubtless a result of in-breeding, for Düsing (Jen. Zeits. f. Naturw., Bd. xvii, p. 827, 1884) has shown that close in-breeding, like a reduced condition of nutrition, is favorable to the production of an excess of males.... In conclusion, the author considers that his studies of the history of the Bieloviejsha bison leave scarcely room for doubt that in-breeding is the cause of the final extinction of most large mammals. Inbreeding must begin and lead gradually but certainly to the extinction of a species when it, through any cause, has become so reduced in numbers as to be separated into isolated colonies."

Influence of Cold during the Reproduction Period.- Exceptional cold waves or unusually prolonged cold seasons may cause a temporary loss of food supply or cause the death of the young, which in northern latitudes are usually born in spring. The diminution or loss of young from this cause might act as the first of a series of destructive effects of a progressive secular change. These may be summarized as follows from actual zoölogical observations ${ }^{2}$ among the Cervidæ: (a) disturbed conditions during the conjugation (pairing, mating, rutting) period; $(b)$ enfeebled (through hunger) condition of females during parturition period; (c) severe weather conditions, ice-storms, crusted snow, prolonged

${ }^{1}$ Büchner, Eugen. Mém. Acad. Impér. des Sci. de St. Pétersbourg, vol. 3, no. 2, 1895, p. 1-30.

${ }^{2}$ Communicated by Mr. Madison Grant, Secretary of the Zoölogical Society of New York. 
wet and sleet at time of birth; $(d)$ bulls unable to protect herds; (e) cows unable to protect young from Carnivora through starved condition, or abandoning them when attacked by wolves; $(f)$ enfeebled and unprotected condition of quadrupeds favorable to increased food supply and consequent multiplication of cursorial and other Carnivora, especially Canidæ and Felidæ.

These zoölogical observations are to a certain extent borne out in paleontology by Leith Adams' (British Fossil Elephants, 1879, part 2, p. 98) observations of the exceptionally large number of milk teeth of elephants found in certain Pleistocene deposits, which appears to indicate a high mortality of the young.

Temperature Control of Fertility and Reproduction.- Merriam ${ }^{1}$ has directed attention to one of the physiological effects of a lowering of temperature, namely, its influence upon diminished or increased fertility and the rate of reproduction in what he has called the 'law of temperature control'. This he has stated as. follows: temperature by controlling reproduction predetermines the possibilities of distribution; it fixes the limits beyond which species cannot pass; it defines broad transcontinental barriers within which certain forms may thrive if other conditions permit, but outside of which they cannot exist, be the other conditions never so favorable, (because the sexes are not fertile).

(1) Temperature. In discussing how species are checked in their efforts to overrun the earth Merriam points out that more important than geographic barriers are the climatic barriers (as observed by Humboldt), and of these that temperature is more important than humidity. First, in 1892, this author attempted to show (Proc. Biol. Soc. Washington, vol. 7, April, 1892, pp. $45,46)$ that the distribution of terrestrial animals is governed less by the yearly isotherm or mean annual temperature than by the total rather than the mean temperature during the period of reproductive activity and of growth (adolescence). This reproductive period in the tropics extends over many months or nearly the whole year, and within the Arctic Circle and summits of high mountains is of two months or less duration. Later, in 1894, results which

1 Merriam, C. Hart. "Laws of Temperature Control of the Geographic Distribution of Terrestrial Animals and Plants." Nat. Geogr. Mag., vol. 6, Dec. 29, 1894. 
Merriam obtained from extensive comparison of temperatures and distribution justified the belief that animals and plants (Lower Austral and tropical types coming from the South) are restricted in northward distribution by the total quantity of heat during the season of development and reproduction. Conversely animals and plants (Upper Austral, Transition, and Boreal types coming from the North) are restricted in southward distribution by the mean temperature of a brief period covering the hottest part of the year. Thus in the Transition Zone, Boreal and Austral types mingle in the equable climate of the Pacific coast of California while they are sharply separated by the inequable extremes of cold and heat of the interior continental plateau.

(2) Humidity, observes Merriam, is a less potent factor than temperature in limiting the distribution of the Mammalia of North America. ${ }^{1}$ (a) Many genera adapted to certain restrictions of temperature zones range east and west completely across the American continent inhabiting alike the humid and arid subdivisions but no genus adapted to certain restrictions of humidity ranges north and south across the temperature zones. (b) Thus humidity governs the details of distribution of a few species of mammals within the temperature zones.

Lowering of Temperature and Diminished Fertility as a Cause of Extinction.- Since the favorable influence of high mean temperature on fertility and reproduction is well illustrated in the reproductive organs of birds and in the early age of reproduction and increased fertility of the human species toward the equator, and since there exist these low-temperature barriers to reproduction, it is highly probable that a secular lowering of temperature may have repeatedly been a cause of extinction in the earth's history; that certain mammals may have resisted exposure to cold or discovered new forms of food and yet suffered extinction through the subtle inhibition of fertility and reproduction.

\section{Increasing Moisture}

Influences of Increased Rain Supply.-Besides the changes in

${ }^{1}$ This would not be true of Africa, of Central America, or other tropical countries where certain insect and disease barriers exist which are favored by moisture. 
plant food which are brought about by diminished moisture, as indicated below, there are the effects of increased moisture which may be equally if not more important. Dry or moderately dry conditions, provided they are not too extreme, are generally more favorable to quadrupeds than moist conditions. The plains and forest regions most densely populated with quadruped life, such as those of the African plateau, are regions of moderate rainfall and even of prolonged summer droughts. The regions least densely populated are regions of heavy rainfall and most dense forests and vegetation, such as those of the equatorial belt of South America or the Congo region of Africa. We observe that:

(1) Increased rainfall may diminish the supply of harder grasses to which certain quadrupeds have become thoroughly adapted.

(2) Increased rainfall may introduce new poisonous or deleterious plants (see p. 790).

(3) It may be the means of introducing new insect and other pests and new insect barriers.

(4) It may be the means of introducing new protozoan diseases, and new insect carriers of diseases.

(5) It may be the means of erecting new forest barriers or new forest migration tracts for certain Carnivora. It follows that periods of secular increasing moisture such as the early Pleistocene of the northern hemisphere is supposed to have been, may have been very unfavorable to certain large quadrupeds, even prior to the advent of extreme cold.

Insect Barriers and Moisture. - It is a matter of universal observation that in tick- or insect-infested countries, generally, dry seasons result in the reduction, moist seasons in the increase of diseases. Dry localities are favorable; moist localities are unfavorable.

Thus A. E. Shipley observes of the tse-tse fly, in his interesting' address ${ }^{1}$ that its " northern limit corresponds with a line drawn from the Gambia, its southern limit is about on a level with the northern limit of Zululand. Most writers agree that the tse-tse is not found in the open veldt, that it must have cover. Warm, moist, steamy hollows, containing water and clothed with forest growth are the haunts chosen." 1

${ }^{1}$ Shipley, Arthur E. "Insects as Carriers of Disease." Nature, vol. 73, no. 1888, Jan. 4, 1906, pp. 235-238. 


\section{Decreasing Moisture. Secular Desiccation}

Secular desiccation has been the fate of portions of three great continents, and on each continent we observe a general concomitant modification and extinction of certain kinds of quadrupeds. The great regions of the world where decreasing moisture has introduced a series of changes ending in the extinction of a great number of quadrupeds are:

(1) North America, Western Plains Region, Arid Plateau and Mountain Region beginning in Oligocene times.

(2) South America, Patagonia and Pampean Region, beginning in late Pliocene times.

(3) North Central Africa, the Fayûm district beginning in Oligocene times.

(4) Central Australia, beginning in Pleistocene times.

The writings of American paleontologists, also of Stirling, of Andrews, and of Ameghino, describe faunæ adapted to much moister conditions than those which prevail at present. We observe that decreasing moisture:

(1) Changes the character of the food supply. Diminution of softer and more succulent vegetation, increase of harder and more resistant vegetation.

(2) Increases length and severity of the dry season.

(3) Removes forest barriers and admits new competitors.

(4) Reduces the water supply and eliminates animals incapable of traveling long distances for food and water.

(5) Favors grazing quadrupeds and eliminates browsing and forest-living quadrupeds.

Prolonged or increasing droughts entirely disturb the balance of nature; they compel migrations; they expose quadrupeds to Carnivora by driving them to restricted water pools. They favor quadrupeds able to dispense with a daily supply of water.

Secular Desiccation and Vegetation.-The indirect influences of secular changes of climate on quadrupeds are apparently quite as important factors in extinction as the direct, namely, changes in vegetation due to diminution of moisture, which render certain types of quadrupeds which were perfectly adapted to one kind of 
plant food, largely or wholly inadapted to the new or altered kinds of food. This we shall show was probably the most potent factor in the extinction of the Titanotheres, of the Chalicotheres, in fact of all the quadrupeds with short-crowned molar teeth, adapted to browsing habits.

The correlation between an initial change of climate and the consequent diminution of the softer kinds of vegetable food and increase of the harder kinds, such as grasses, followed by the extinction of a very large number of Herbivora, was first thoroughly worked out in an epoch-making memoir of Waldemar Kowalevsky in 1873 .

Droughts and Numerical Diminution.- Darwin ${ }^{1}$ describes the devastating effects of the great drought in the Pampas between 1827 and 1830 in which great numbers of birds, wild animals, cattle, and horses, perished from want of food and water. The cattle perished by thousands on the muddy banks of the Parana River. Similarly Azara describes the horses perishing in large numbers in the marshes.

Increasingly prolonged summer droughts were characteristic of the late Miocene and Pliocene of Europe, and we are beginning to accumulate evidence that the same conditions prevailed in North America.

Influence of Droughts in Central Africa.- The influence of the gradual decrease of moisture in a country is clearly illustrated in the conditions which prevail in the African continent to-day, as observed by such writers as Gregory, ${ }^{2}$ Foa, and Schillings. Thirst, like hunger, first drives quadrupeds to take extreme risks, which they would absolutely avoid during natural conditions. The drinking-places or water-pools during long seasons of drought become fewer in number and more widely separated, and large animals driven to them by thirst are more readily attacked and killed by Carnivora. The pools become separated by distances of thirty and forty miles, thus necessitating long excursions to and from the various feeding places, in which the quadrupeds are

${ }^{1}$ Darwin, Chas. Journal....Voyage of H. M. S. Beagle around the World, p. $128-130$.

${ }^{2}$ Gregory. The Great Rift Valley.... 8vo. London, 18๕6. 
again exposed to attack. Finally some of the pools dry up entirely and, as observed by Gregory, (p. 268): "Here and there around a water hole we found acres of ground white with the bones of rhinoceroses and zebra, gazelle and antelope, jackal and hyena .... all the bones were there fresh and ungnawed...." These animals, which had not migrated, had "crowded around the dwindling pools and fought for the last drops of water."

Such perishing of animals in great numbers from thirst would bring about the condition of diminished herds spoken of above as the final cause of extinction through inability to protect the young. Alkali and Salt Deposits. - One effect of increasing desiccation is the increased number of alkali lakes, licks, and springs, and other localities of salt deposits. Alkali is much sought by certain wild animals as a substitute for salt. Western stock-raisers disagree as to the effects of alkali upon sheep and cattle, some believing that it cannot take the place of salt. Chestnut (1901, p. 20) notes that alkali may possibly predispose to the 'loco habit,' the eating of a narcotic weed (see p. 791). When domesticated animals are not salted regularly they soon discover localities where large quantities of alkali are found in the soil and visit such places frequently for the purpose of eating this alkali soil (Chestnut, 1901, p. 87$).{ }^{1}$

Desiccation and Extinction in Central Australia.-Wallace's opinion as to Australian extinction has been cited more with reference to the effect of Glacial-Epoch conditions and continental contraction in general than as to the special causes of extinction in Australia.

More recent research as set forth by the geologist Professor Tate, ${ }^{2}$ the zoölogists Hedley ${ }^{3}$ and Baldwin Spencer, show that in Pliocene times heavy rainfall or pluvial conditions, great inland

${ }^{1}$ Chestnut, V. K., and Wilcox, E. V. "The Stock-poisoning Plants of Montana: A Preliminary Report." U. S. Dept. of Agric., Div. of Botany, bull. 26, 1901.

2 "On the Influence of Physiographic Changes in the Distribution of Life in Australia." Austr. Ass. Adv. Sci., vol. 1, pp. 312-325, 1889. Quoted by Baldwin Spencer. Through Larapinta Land; A Narrative of the Horn Expedition to Central Australia, Part 1, p. 159, 1896.

2 "The Faunal Regions of Australia." Austr. Ass. Adv. Sci. Adelaide, 1893. 
seas or freshwater lakes (first surmised by Stuart) favored the development of large marsupials. Conversely the rise of an eastern coastal range was followed by diminished rain supply and progressive desiccation of the interior region.

Spencer observes: ${ }^{1}$ "The larger forms now extinct, such as species of Diprotodon, Nototherium, Phascolonus, Macropus, Protemnodon, etc., reached their greatest development in Pliocene times and were characteristic of the eastern interior, spreading southward round the western end of the Dividing Range into Victoria. They do not seem to have reached the eastern coastal district..... In Post-Pliocene times, with the increasing desiccation of the whole central area they became extinct, though this. extinction cannot be attributed wholly to the drying up of the land, because in certain parts, such as Western Victoria, to which they reached, the state of desiccation did not supervene; but at the same time it may perhaps be justly argued that the desiccation of the vast area of the interior was the largest factor in their extinction."

The discovery (1892) of the great Lake Callabonna bone deposit in the interior of South Australia abundantly confirms the 'desiccation' theory. Dr. E. C. Stirling ${ }^{2}$ describes this remarkable deposit as follows: -

"There is, however, compensation for the unpromising physical features of Lake Callabonna in the fact that its bed proves to be a veritable necropolis of gigantic extinct marsupials and birds which have apparently died where they lie, literally, in hundreds. The facts that the bones of individuals are often unbroken, close together and, frequently, in their proper relative positions (vide pl. A, fig. 3), the attitude of many of the bodies and the character of the matrix in which they are embedded, negative any theory that they have been carried thither by floods. The probability is, rather, that they met their death by being entombed in the effort to reach food or water, just as even now happens in dry

${ }^{1}$ Spencer, Baldwin. Report of the Horn Expedition to Central Australia. Summary of the Zoological, Botanical and Geological Results of the Expedition, 1896 , p. 183.

${ }^{2}$ Stirling, E. C. "Fossil Remains of Lake Callabonna." Mem. Roy. Soc. of South Australia, vol. 1, pt. 2, pp. ii-iii. 
seasons, to hundreds of cattle which, exhausted by thirst and starvation, are unable to extricate themselves from the boggy places that they have entered in pursuit either of water or of the little green herbage due to its presence. The accumulation of so many bodies in one locality points to the fact of their assemblage around one of the last remaining oases in the region of desiccation which succeeded an antecedent condition of plenteous rains and abundant waters. An identical explanation has been suggested by Mr. Daintree ${ }^{1}$ in his 'Notes on the Geology of the Colony of Queensland.",

\section{Living Environment. Plant Life}

Under climate we have considered the relations of cold, heat, moisture, and desiccation to hunger, thirst, the feeding and migrating habits of animals. We may now look at the food supply of the Herbivora in relation only to unusual conditions of life.

Forestation, Deforestation, and Reforestation.- Forests furnish the necessary conditions of life of certain quadrupeds, especially of the browsers and of the Proboscidia. Among Artiodactyla the deer, among Perissodactyla the tapirs are typical forest animals. Conditions, therefore, which cause deforestation would become a means of extinction; such conditions are $(a)$ intense cold and heavy snow capping, $(b)$ intense dryness, $(c)$ destruction of young trees by the smaller browsing animals. It is probable that the interior of Australia and the Pampean region of South America were in Pliocene and early Pleistocene times partially covered with forests. It is certain that the Holarctic region or circumpolar belt was forested in the early Pleistocene. Our western arid region was extensively forested at one period. Several of the smaller islands of the Mediterranean have been deforested. Reforestation would confine and limit the desert and plains types. Progressive moisture and reforestation would be very unfavorable to the horse (see Morris, 1895, p. 261). Thus both migration. barriers and migration tracts are formed by forests.

${ }^{1}$ Quart. Journ. Geol. Soc., vol. 28, 1872, p. 275. 


\section{A New or Altered Food Supply}

Poisonous Plants.-Plants which are fatal to some Herbivora are innocuous to others. Linnæus in his Tour in Scania tells us, as cited by Lyell " "that goats were turned into an island which abounded with the Agrostis arundinacea, where they perished by famine; but horses which followed them grew fat on the same plant. The goat, also, he says, thrives on the meadow-sweet and water-hemlock, plants which are injurious to cattle." ${ }^{2}$

We must be extremely cautious not to substitute artificial conditions or those brought about by the agency of man for purely natural conditions. In speaking of the deaths caused by the twenty-five species of stock-poisoning plants found in Montana, Chestnut ${ }^{3}$ observes: "But all these causes operate much less effectively against buffaloes and other ruminants in the wild state for, in the first place, being bred there under perfectly natural conditions, and being abundantly able to roam over long distances in search for food and water, they naturally reject all but the best and most wholesome diet. Then in the winter they migrate to the south, where the conditions for their existence were more favorable....Besides, it would require a large quantity of any of the common poisonous plants to kill an animal of such size."

Observations in South Africa ${ }^{4}$ give similar results. The 'chinkerinchee' plant (Ornithogalum) is poisonous to horses, and one of the ragworts (Senecio) is an irritant causing cirrhosis of the liver in cattle and horses. Other plants which give trouble are tulps (species of Moræa). The losses are chiefly among cattle not accustomed to the country, or amongst very hungry trek cattle.

It is true, first, that animals generally but not invariably learn to avoid poisonous plants, second, that they become more or less immune to their deleterious effects, third, that often it is solely

${ }^{1}$ Principles of Geology, vol. 2, p. 440, 1872.

${ }^{2}$ Ibid., vol. 7, p. 409.

3 "Some Poisonous Plants of the Northern Stock Ranges." Yearbook Dept. Agriculture for 1900, Washington, pp. 308-309.

${ }^{4}$ Kindly communicated by Charles P. Lounsbury, of the Department of Agriculture, Cape of Good Hope. See Agricultural Journal, February, 1906. 
the influence of hunger which drives them to eat poisonous plants. This justifies the consideration of plants under unusual conditions of life among the possible causes of extinction. The presence of molds and smuts which appear on the Graminex, the introduction and spread of certain narcotic plants, the influence of ergot in causing diseases of the hoof, the relation of poisonous plants to increased or diminished rainfall, the introduction of certain poisonous plants which while not injuring the parent affect and frequently kill the suckling young may be considered. Lambs are frequently killed by sucking milk from animals which had fed on the death camas, Zygadenus venenosus. ${ }^{1}$

\section{Dangers Heightened by Harsh or Unusual Conditions of Life}

Poisonous plants are widely distributed. Under the unnatural conditions of extreme cold, drought, enforced migration, starvation, etc., it is not impossible that they may have exerted some influence especially on diminishing herds. The following observations are chiefly brought together from the papers of Dr. V. K. Chestnut of the U. S. Agricultural Bureau. This author states in a letter dated July 9, 1902: "So far as my observations have extended the chief circumstance leading to death from poisonous plants is an irregularity of the food supply caused by more or less unusual conditions. It does not seem reasonable to suppose that wild animals are frequently poisoned in their native grazing grounds. Sudden disasters, however, might drive them from their feeding grounds into pastures quite unfamiliar to them, where they would undoubtedly be more or less at a loss to distinguish between poisonous and non-poisonous plants."

The following observations $(a, b, c)$ apply to domesticated Herbivora.

(a) Varying Effects of Wet and Dry Months. - Chestnut ("StockPoisoning Plants of Montana" 1901, p. 19) observes that the majority of plants known to be especially poisonous during the wet months are so shriveled and dry in the dry months as to be

\footnotetext{
${ }^{1}$ Chestnut, V. K., and Wilcox, E. V. Stock Poisoning Plants of Montana. p. 61 .
} 
absolutely unpalatable. Sheep owners have accordingly found mountain ranges which are extremely dangerous for sheep during the wet months of early summer, quite safe during the months from July to September inclusive. Similarly, during the wet season and when feeding immediately after heavy rainstorms. domesticated animals are more apt to pull up the roots of plants. than when the ground is dry (Chestnut, 1901, p. 26), and, as is well known, in the case of many poisonous plants it is the roots. which chiefly contain the active principle.

(b) Fatal Effects of Snowstorms. - After heavy snowstorms. when the grass is covered by snow it often happens that only the taller species of plants are exposed (Chestnut, 1901, p. 27). In such cases the poisonous larkspurs (Delphinium glaucum) are greedily eaten by cattle, which would otherwise avoid these plants. This tendency is increased by the fact that ruminants do not feel at ease so long as the stomach is not full and are inclined to eat anything in sight after a snowfall. In seasons of drought certain poisonous leguminous plants remain green and tempting after the grasses have become thoroughly dried. Under these conditions cattle on the range are known to take the loco and lupin (Chestnut, 1901, p. 29).

(c) Fatal Effects of Enforced Migration.-It is observed (Chestnut, 1901, p. 21) among domesticated animals that when feeding quietly on the range they exercise considerable choice in the selection of forage plants, but when being driven six or eight miles a day they are frequently forced by hunger to bite off almost all kinds of plants which grow along their course. Enforced migration among wild animals might similarly cause them to become less fastidious about food.

\section{Dangerous Plants Favored by Moisture}

Poisonous Plants of Montana.-The chief poisonous plants of the Montana stock ranges (Chestnut, 1901) are: the death camas. (Zygadenus), favored by moderate moisture and taken by sheep; the "tall larkspur" (Delphinium glaucum), favored by moderate moisture, taken by cattle; the "purple larkspur" (D. bicolor), taken by sheep; the water hemlock (Cicuta), found along water 
courses, taken by cattle and sheep; the white loco (Aragallus), taken by horses, sheep, and cattle. Lupines (Lupinus) in certain stages of growth are poisonous to sheep. Ergot (Claviceps purpurea), occurs in Montana on a variety of grasses, and is occasionally poisonous to horses and cattle, producing a disease of the limbs. On a large ranch of Wyoming, ergot is reported (Walter Granger, letter, 1904) to have appeared as a result of irrigation rendering a large tract fatal to horses and cattle by causing a disease of the hoofs.

A leguminous plant of Egypt, Lotus arabicus, recently investigated by Dunstan and Henry, ${ }^{1}$ as a growing plant, is quite poisonous to horses, sheep, and goats. Its seeds when ripe are commonly used as fodder. It contains a glucecoid termed 'lotusin,' which is poisonous when taken into the stomach (Chestnut, 1902).

Narcotic Plants. - Among narcotic plants 'loco weeds' are the most interesting'. 'Loco' is a Spanish word meaning mad or crazy, and is applied in northern Mexico and southern United States to certain plants which so affect the brain of animals as to give them all the symptoms of brain disease. As described in the important papers of Chestnut ${ }^{2}$ the weeds called 'loco' belong to genera of the bean family. "For many years," this writer observes, "a disease callerl loco, affecting cattle, horses, and sheep, has been generally known to the stockmen of the western ranges. This disease has most commonly been attributed to the action of certain plants, more rarely to that of alkali. Several species of plants have been suspected of producing the loco condition in animals and have been called loco plants or loco weeds and also crazy weeds from the nature of the disease. Nearly all of the plants. which have been considered loco weeds belong to two genera of the pea family, Astragalus and Aragallus. These genera are represented by numerous species on the Western stock ranges.... (p. 87)....From a general description given of the loco disease it is apparent that this condition might very justly be termed a. perverted appetite... The horse and the sheep are the animals

1 "Problems in the Chemistry and Toxicology of Plant Substances." Science, n. s., vol. 15, no. 391, June 27, 1902, pp. 1016-1028.

${ }^{2}$ Chestnut, V. K. "Preliminary Catalogue of Plants Poisonous to Stock." Ann. Rep. Bur. of Anim. Indus., 1898, pp. 403, 404. 
which are most frequently affected by loco disease. Cattle occasionally acquire the loco habit, but the cases are comparatively rare. In certain parts of Montana the habit became so widespread among horses that the raising of them was abandoned until the locoed animals were disposed of and other horses which had not the loco habit had been imported" (p. 89). "During the progress of field work in Montana in 1900, about 650 locoed sheep and 150 locoed horses were seen ${ }^{1}$ (p. 90).

Mechanically Dangerous Plants.-There occur in Montana occasional losses of stock from plants acting mechanically. For example, the sharp-barbed awns of the porcupine grass (Stipa spartea) and squirreltail (Hordeum jubatum) when the plants are maturing, separate, and entering the mouth, throat, eyes, and ears of stock, affect the tissues and give rise to ulcers which cause intense suffering and necessitate killing. ${ }^{2}$ Similarly the corn-stalk disease is sometimes attributed to malnutrition or impaction of the alimentary canal.

In this connection may also be cited an observation recorded by Thistleton-Dyer ${ }^{3}$ which happens to bear upon the life of goats. "The introduction of the sweet briar into New South Wales, Australia, in many parts of which it is naturalized, affords a striking illustration of the mode in which the balance of nature may be disturbed in a wholly unforeseen way.... The fruit of the sweet briar (Rosa rubiginosa) consists of a fleshy receptacle lined with silky hairs which contains the seed-like carpels..... The hairy linings of the fruit caused the death of a number of goats by forming hairy calculi, which mechanically occluded the lumen of the bowels. These goats were put on the land with the idea that they would eat down the briars and ultimately eradicate them, but the briars came out best and eradicated the goats. The cattle running on the land are also very fond of the briar berries, and

${ }^{1}$ Chestnut, V. K., and Wilcox, E. V. "The Stock-Poisoning Plants of Montana: A Preliminary Report." U. S. Dept. of Agric. 1901, bull. 26, pp. 87-90.

${ }^{2}$ Chestnut, V. K. "The Stock-Poisoning Plants of Montana. A Preliminary Report." U. S. Dept. of Agric., 1901, bull. 26, pp. 50-51.

3 "The Sweet Briar as a Goat-Exterminator." Nature, vol. 66, no. 1697, May 8, 1902, p. 31. 
from time to time one will die, and on post mortem [examination] no pathological changes can be found in any of the organs, nor do the hairy calculi appear in them, although their various stomachs are one mass of the briar seeds."

\section{Living Environment. Insect Life}

The features of physical environment such as moisture and desiccation, forestation and deforestation, heat and cold, cannot be considered by themselves or solely in relation to plant life but in relation to the insect life which they condition and which indirectly becomes the barriers and even the exterminators of mammalian life.

We may first consider the influence of the introduction into habitual feeding grounds of various forms of insect life which render these grounds practically uninhabitable and either kill or drive the animals out. Thus Wallace ${ }^{1}$ observes: "The next case I will give in Mr. Darwin's own words: 'In several parts of the world insects determine the existence of cattle. Perhaps Paraguay offers the most curious instance of this; for here neither cattle nor horses nor dogs have ever run wild, though they swarm southward and northward in a feral state; and Azara and Rengger have shown that this is caused by the greater numbers, in Paraguay, of a certain fly which lays its eggs in the navels of these animals when first born. The increase of these flies, numerous as they are, must be habitually checked by some means, probably by other parasitic insects. Hence, if certain insectivorous birds were to decrease in Paraguay, the parasitic insects would probably increase; and this would lessen the number of the navel-frequenting flies - then cattle and horses would become feral, and this would greatly alter (as indeed I have observed in parts of South America) the vegetation: this again would largely affect the insects, and this, as we have just seen in Staffordshire, the insectivorous birds, and so onward in ever-increasing circles of complexity....",

The two-horned rhinoceros ( $R$. bicornis) of Africa as well as

${ }^{1}$ Wallace, Alfred R. Darwinism, 1889, p. 19. 
some members of the antelope family are well known to be protected from insects by birds (see Millais's Breath of the Veldt, and other works). Anyone who has watched the sufferings of cattle and horses from flies knows that insects may become an important factor in expelling animals from a certain country to which they are naturally adapted by their tooth and foot structure.

Ticks.-Ticks, even when non-infection-bearing, form absolute and effective barriers to the introduction of quadrupeds into certain regions. In certain forested portions of South and Central America. they endanger human life. In certain regions of Africa ticks are practically fatal to horses; as observed by Dr. D. G. Elliot thousands of ticks would sometimes gather on a horse as a result of a single night's grazing. The mane especially serves to collect these pests. Thus the falling mane of the northern horse is distinctly disadvantageous as compared with the upright manes of the asses and zebras. Ticks are capable of driving certain types of animals entirely out of a country and of indirectly causing certain modifications of the hair and epidermis.

Frontal Air Sinuses.-Larvæ invading the frontal sinus of the skull are not to be left out of account among the possible causes of elimination. An old trapper and close observer in British Columbia, Mr. Charles Smith, informs me that both the wild sheep of the region (Ovis montana) and the wapiti (Cervus canadensis) are seriously affected and sometimes killed by inflammation caused by these larvæ. The over-crowded caribou of Labrador and Newfoundland suffer from a fly which lays its eggs in the nostril passages.

In certain of the Eocene Titanotheres, in Dolichorhinus especially, the frontal air sinuses communicate with sinuses extending completely back to the occiput. The invasion of such sinuses by larvæ would undoubtedly be very harmful if not fatal.

Insects and the Food Supply.-The periodic devastations of certain insects especially those caused by locusts as cited by Lyell in Europe, Arabia, India, and Northern Africa, are quite sufficient to cause the extinction of certain species. As Lyell concludes: ${ }^{1}$ "The occurrence of such events at certain intervals, in hot countries,

${ }^{1}$ Lyell, C. Principles of Geology, vol. 2, 1872, p. 445. 
like the severe winters and damp summers returning after a series of years in the temperate zone, may affect the proportional numbers of almost all classes of animals and plants, and probably prove fatal to the existence of many which would otherwise thrive there; while, on the contrary, the same occurrences can scarcely fail to be farourable to certain species which, if deprived of such aid, might not maintain their ground."

(To be continued) 